\title{
Correlation Among Learning Styles, Learning Strategies and Speech Act of Request Realization of the Eleventh Grade Students of SMAN 2 Kasui Way Kanan
}

\author{
Khairil Akhyar ${ }^{1 *}$, Rusman Roni ${ }^{2}$, Mulyadi $^{3}$ \\ ${ }^{1}$ SMAN 2 Kasui Way Kanan, Indonesia \\ ${ }^{2}$ Universitas Tridinanti Palembang, Indonesia \\ ${ }^{3}$ Universitas PGRI Palembang, Indonesia \\ *Corresponding author. Email: akhyarnursiana@gmail.com
}

\begin{abstract}
The identification of learning styles and the implementation of successful learning strategies have a significant impact on English teaching and learning as a native language. The objective of the study is to find out the correlation among language learning styles, learning strategies and the speech act of request realization. It is a quantitative analysis that used a correlation research design. The information was gathered by distributing questionnaires and conducting role play. 60 students of the $11^{\text {th }}$ grade students of SMA Negeri 2 Kasui Way Kanan in the academic year 2020/2021 were chosen as sample. The study's findings revealed a positive relationship among learning styles and the speech act of request realization, learning strategies and the speech act of request realization, learning styles and learning strategies and the last correlation among learning styles, learning strategies and the speech act of request realization.
\end{abstract}

Keywords: Learning Styles, Learning Strategies, Speech Act of Request

\section{INTRODUCTION}

Learning language involves complex things and aspects. What makes it complex relates to having to listen, talking, learning, and drafting are the four primary skills, and also the language aspects, i.e. phonology, pragmatic, semantic and syntax. The challenge persists in the teaching-learning process. Definition of learning is as changing of mental representation or associations for long term as a result of experience [1]. According to research, several factors contribute to the learning of English language. There are two types of factors: external forces and individual characteristics. External forces are those that exist outside of an individual learner, for example the environment, curriculum, teachers and learning facilities. One of the most important things in external factor is how learners get comprehensible output as much as possible. Individual learning necessitates an individual, autonomous learner who is willing to use a variety of successful learning methods [2].

While the external factors come from the outside of an individual learner, the internal factors come from the inside of an individual learner. They are the cognitive factors such as language aptitude, affective factors such as motivation, personality and attitude, as well as innate personal factors such as gender, age and cultural background.

As a matter of a fact, the challenge, again, does not stop. Other factors can affect a person's positive attitudes towards learning English as an additional language. Learning style and learning techniques are the influences. The definition of learning style has recently gained attention in the context of education [3] Learning Styles has been regarded as one of the most important factors that control the way pupils learn. Learning-style evaluation proponents argue that optimal teaching necessitates diagnosing individuals' learning styles and tailoring instruction accordingly [4]. There is also a propensity to match students' learning styles to the "teaching styles" of concerned teachers [5]. Teaching method being termed as internal characteristics of a learner that are often not interpreted or actively said by the student for both the absorption and interpretation of newfound information, while learning strategy is defined as the exterior skills that people implement intentionally to learn at their own pace [6]. There are three types of learning styles: cognitive, personality (psychology), and sensory [7]. Learning styles and learning methods are essentially two distinct perspectives on [8]. 
In an attempt of gaining communication effectively, suggests four conversational maxims under the Cooperative Principle (CP) named quantity, quality, relation, and manner [9]. Quantity means giving the right amount of information, not making the contribution more informative than is required; quality means contributing true information, not saying what the speakers believe to be false; relation means giving the relevant information; and manner means giving perspicuous information, not giving ambiguity and in order contribution.

In other words, the success of a cross culture communication lies in the stage when what the speaker intended to express is heard clearly by the hearer, there is comprehension to the listener's understanding of the speaker's meaning, and there is an effect of the speaker's utterance.

The successful conversation is highly affected by the communicative competence between the speakers. Communicative competence is the qualification to comprehend and utilize a certain language in effective and efficient way in order to deliver the communication in social and school environment authentically. Linguistic competence acknowledged four competencies in communicative competence. The competencies are strategic competence, sociolinguistic competence, and discourse competence. Since it is crucial to master the sociolinguistic competence in communication, the mastery of pragmatics competence has been unavoidably important. Pragmatics is a study which lies on the way of thinking that way of communication is more important than the topic that is communicated. The utterances that the speakers delivered in communication encompass deeper meaning than the real substance of the words or phrases themselves. Pragmatics consequently related more to the analysis of what people actually wish to express by their sentences than what is the meaning of the words or phrases themselves. Pragmatics correlated to the context or situation when something is being spoken, thus it is very important for the speakers to focus on the context.

Speech act is one of the aspects of pragmatic. The term "speech act" is defined as how the words that a speaker utilize may give contribution in the action of the speaker and the listener in a communication. As the part of pragmatics, speech act goals at behind meaning of the words or phrases when a speaker utters certain sentences. Speech acts are to the operation executed by certain sentences. People may execute an operation by producing utterances. By employing speech acts, the speaker may deliver a certain activity only by saying certain words, phrases or utterances.

It is unarguable that everyone must have their own learning styles applied in language learning. In the language acquisition, it is undeniable that each person, whether it is consciously or subconsciously, may apply certain strategies to be successful in learning. Each instructor has a distinct teaching style, as do the learning styles of their students, which can have an effect on their academic success [10]. The learning style that a learner possesses might have determined the learning strategies he or she apply. Thus, in this research, the writer aimed to gain deeper knowledge how two aspect of language learning might correlate to each other. Further, the writer aimed to find out how the correlation of learning styles and Study skills can obstruct the selection of the speech act of request realization.

In the literature, different concepts such as study skills, thinking styles, physical sensitivity, and personality styles have been used. A few of these terms have already been used different meanings in certain ways, while others have been distinguished in others. Learning styles are described as "the complex manner and conditions in which learners more effectively interpret, process, store, and remember what they are attempting to learn," while cognitive styles are defined as "an individual's normal, habitual, and preferred way (s) of absorbing, processing, and retaining new knowledge and skills." distinguish between learning styles and cognitive styles [7].

Speech acts are any acts that accomplished by saying and meaning that someone is performing so. They have been seized by many to be the core parts of communication, with morphological, phonological, semantic and syntactic properties of an utterance functioning as the form of identifying whether the speaker is intended to make a prediction, a statement, a promise, or a threat. Many of speech acts are actually consequential, because a proper authority can, say, declare war or sentence a defendant to prison by saying that she is doing so.

In another study formulates the sub-strategies of query preparatory strategies based on the function of the modals. The six sub-strategies are: 
Table 1. The sub-strategies of query prepatory strategies

\begin{tabular}{|c|l|l|}
\hline No & \multicolumn{1}{|c|}{ Modals } & \multicolumn{1}{c|}{ Examples } \\
\hline 1 & $\begin{array}{l}\text { Can/ Could } \\
\text { (a) Can/ Could I/ you } \\
\text { (b) Do you think (that) I/ } \\
\text { you can/ could }\end{array}$ & $\begin{array}{l}\text { "Can I postpone the exam? I have to } \\
\text { "Carticipate in wedding at that time" } \\
\text { because I can"t study" }\end{array}$ \\
\hline 2 & $\begin{array}{l}\text { Will/ would } \\
\text { (a) Will/ would I/ you } \\
\text { (b) I would appreciate it if }\end{array}$ & $\begin{array}{l}\text { "Oh, I missed the last class; will you please } \\
\text { lend me your notes?" } \\
\text { "Would you slow down the music please? } \\
\text { I'm studying" }\end{array}$ \\
\hline 3 & May & $\begin{array}{l}\text { "Professor, may I have the test another day?" } \\
\text { "May I sit here, please?" }\end{array}$ \\
\hline 4 & $\begin{array}{l}\text { Mind (do/ Would you } \\
\text { mind) }\end{array}$ & $\begin{array}{l}\text { "Excuse me Sir, would mind taking a picture } \\
\text { of us?" } \\
\text { "Excuse me, would you like to take a photo } \\
\text { for us, if you don"t mind" }\end{array}$ \\
\hline 5 & Possibiliy & $\begin{array}{l}\text { "It is possible for you to take one picture for } \\
\text { us" }\end{array}$ \\
\hline 6 & I was wondering & $\begin{array}{l}\text { "I was wondering if you have time to write } \\
\text { recommendation letter for me" }\end{array}$ \\
\hline
\end{tabular}

\section{METHODS}

This quantitative study involves students of the elevent grade of SMA N 2 Kasui Way Kanan. As many as 60 students were selected randomly. The data were collected through two sets of questionnaire to gain the data of learners' learning style and learners' learning strategy, and a role play was conducted to gain the data of students' speech act of request realization.

Then the writer analyze the table of request strategy types realized by the students. The analysis focused on each type requests used by the students.

\section{RESULTS AND DISCUSSION}

From the table it is shown that the speech act of request type 1 was mostly employed by the communicate-social learners. While the speech act of request type 2 was employed evenly by authorityoriented- metacognitive and undecided meta-cognitive learners. The speech act of request type 3 which was not really much employed in the dialog by the students, appeared twice by undecided-cognitive learners. The speech act of request type 4 , which was only employed by 6 students in the dialog, appeared once at a time by Communicative-meta-cognitive, communicative-social, concrete-cognitve, authority-oriented-meta-cognitive, authority-oriented-social and analytic-meta-cognitive learners. Further, the speech act of request type 5 which was only employed by 4 students, appeared mostly from communicative-social learners. The last speech act of request type.

Table 2. The distribution of students Learning styles, Learning Strategies and Speech Act of Request Realization

\begin{tabular}{|c|c|c|c|c|c|c|c|c|c|}
\hline \multirow{2}{*}{ No } & \multirow{2}{*}{ Styles } & \multirow{2}{*}{ Strategies } & \multicolumn{6}{|c|}{ Speech Act of Request Realization Types } & \multirow[t]{2}{*}{ Total } \\
\hline & & & 1 & 2 & 3 & 4 & 5 & 6 & \\
\hline \multirow{3}{*}{1} & \multirow{3}{*}{ Communicative } & Cognitive & 0 & 1 & 0 & 0 & 0 & 0 & 1 \\
\hline & & Meta-Cognitive & 2 & 0 & 1 & 1 & 0 & 0 & 4 \\
\hline & & Social & 4 & 2 & 1 & 1 & 2 & 0 & 10 \\
\hline \multirow{3}{*}{2} & \multirow{3}{*}{ Concrete } & Cognitive & 2 & 2 & 1 & 1 & 0 & 0 & 6 \\
\hline & & Meta-Cognitive & 1 & 0 & 1 & 0 & 0 & 1 & 3 \\
\hline & & Social & 1 & 1 & 0 & 1 & 1 & 0 & 4 \\
\hline \multirow{3}{*}{3} & \multirow{3}{*}{$\begin{array}{l}\text { Authority- } \\
\text { Oriented }\end{array}$} & Cognitive & 0 & 1 & 1 & 0 & 0 & 0 & 2 \\
\hline & & Meta-Cognitive & 3 & 3 & 1 & 1 & 1 & 1 & 10 \\
\hline & & Social & 0 & 0 & 0 & 1 & 1 & 0 & 2 \\
\hline \multirow{3}{*}{4} & \multirow{3}{*}{ Analytic } & Cognitive & 1 & 2 & 1 & 0 & 0 & 0 & 4 \\
\hline & & Meta-Cognitive & 2 & 1 & 1 & 0 & 0 & 0 & 4 \\
\hline & & Social & 0 & 0 & 0 & 0 & 0 & 0 & 0 \\
\hline \multirow{3}{*}{5} & \multirow{3}{*}{ Undecided } & Cognitive & 2 & 0 & 2 & 0 & 0 & 0 & 4 \\
\hline & & Meta-Cognitive & 1 & 3 & 0 & 0 & 0 & 0 & 4 \\
\hline & & Social & 1 & 1 & 0 & 0 & 0 & 0 & 2 \\
\hline & & TOTAL & 22 & 16 & 10 & 6 & 4 & 2 & 60 \\
\hline
\end{tabular}

From the data analysis of correlation between learning style and speech act of request realization it is shown that the $\mathrm{p}$ value is 0.000 , then we can interpret that there is a strong connection between study skills and speech act of request realization ( $p<0.005)$. Further, since the $r$ value is 0.463 , so it can be interpreted that the correlation is moderate. From the data analysis of correlation between learning strategies and speech act of request realization, it is shown that the $\mathrm{p}$ value is 0.000 , then we can interpret that there is a significant correlation between learning style and speech act of request realization $(\mathrm{p}<0.005)$. Further, since the $r$ value is 0.558 , so it can be interpreted that the correlation is moderate. 
Table 3. Study Habits and Studies On the effects Correlation

\begin{tabular}{|ll|r|r|}
\hline & & Learning styles & Leaming strategies \\
\hline \multirow{3}{*}{ Leaming styles } & Pearson Correlation & 1 & $.782^{\prime \prime}$ \\
& Sig.(2-tailed) & & .000 \\
& $\mathrm{~N}$ & 60 & 60 \\
& Pearson Correlation & $.782^{*}$ & 1 \\
Leaning strategies & Sig.(2-tailed) & .000 & \\
& $\mathrm{~N}$ & 60 & 60 \\
\hline
\end{tabular}

${ }^{* *}$ Correlation is significant at the 0.01 level (2-tailed).

From the data analysis of Study Habits and Studies On the effects Correlation, it is shown that the $\mathrm{p}$ value is 0.000 , then we can interpret there really is a strong connection among study skills and speech act of request realization ( $p<0.005)$. Further, since the $r$ value is 0.782 , so it can be interpreted that the correlation is strong.

Table 4. Correlation Between Learning Styles Learning Strategies and Speech Act of Request Realization

\begin{tabular}{|c|c|c|c|c|c|c|}
\hline \multirow[t]{2}{*}{ Mod } & & \multicolumn{2}{|c|}{ Unstandardized Coefficients } & \multirow{2}{*}{$\begin{array}{c}\text { Standardized } \\
\text { Coefficients } \\
\text { Beta }\end{array}$} & \multirow[t]{2}{*}{$\mathrm{T}$} & \multirow[t]{2}{*}{ Sig. } \\
\hline & & B & Std. Error & & & \\
\hline \multirow{3}{*}{1} & (Constant) & 2.934 & 11.621 & & .220 & .831 \\
\hline & Leaming Styles & .192 & .215 & .190 & .894 & 395 \\
\hline & Leaming Strategies & 888 & .249 & .760 & 3.567 & .006 \\
\hline
\end{tabular}

\section{CONCLUSION}

From the study it can be concluded that: 1) there is a strong connection among study skills and the communicative functions of request realization. The relationship is mild; 2) there is a strong connection among learning techniques and the speech act of request realization. The relationship is mild; 3) there is a clear connection between learning styles and learning strategies. The relationship is solid, and 4) there is a close association between learning styles, learning techniques, and the speech act of request realization.

\section{ACKNOWLEDGMENTS}

Our deepest gratitude goes to Teachers in SMAN 2 Kasui Way Kanan, Chancellor of Palembang PGRI University, Director of the Postgraduate Program of PGRI Palembang University and the Education Management Study Program of PGRI Palembang University, who have supported us in doing this extraordinary thing. This project is funded independently. We also want to thank our Education Management friends who helped us a lot in a short time frame to complete this project.

\section{REFERENCES}

[1] Isrona, L. (2015). Decription of Students' Learning Style. Jurnal Kesehatan Andalas, Vol 4, No 2.

[2] Cimermanová, I. (2018). The Effect of Learning Styles on Academic Achievement in Different
Forms of Teaching. International Journal of Instruction Vol.11, No.3.

[3] Bhat, M. A (2014). Understanding the Learning Styles and its Influence on Teaching/Learning Process. International Journal of Education and Psychological Research (IJEPR) Volume 3, Issue 1, pp: 14-21.

[4] Pashler, H., McDaniel, M., Rohrer, D., \& Bjork, R. (2009). Learning Styles Concepts and Evidence. Psychological Science in The Public Interest Volume 9 Number 3.

[5] Jaleel, S., \& Thomas, A. M. (2019). Learning Styles: Theories and Implications for Teaching Learning. USA: Horizon Research Publishing.

[6] Wong \& Nunan. (2011). The Learning Styles and Strategies of Effective Language Learners. Science Direct Journal. University of Hongkong. Hongkong.

[7] Awla, H. A. (2014). Learning Styles and Their Relation to Teaching Styles. International Journal of Language and Linguistics Vol. 2, No. 3, 2014, pp. 241-245. doi: 10.11648/j.ijll.20140203.23

[8] Soundariya, K., Deepika, V., \& Kalaiselvan, G. (2017). A study on the learning styles and learning approaches among medical students. National Journal of Physiology, Pharmacy and Pharmacology Vol 7, Issue 10.

[9] Seniarika. (2016). The Realization of EFL Learners' Requests and the Cross-Cultural Perceptions on the Politeness of the Request at SMA Tunas Mekar Indonesia Bandar Lampung. A 
Thesis. Bandar Lampung. University of Lampung Press.

[10] Ridwan, H., Sutresna, I \& Haryeti, P. (2019). Teaching styles of the teachers and learning styles of the students. Journal of Physics: Conference Series 1318. 